RESEARCH ARTICLE

\title{
Role of human agency in the transformation of the biogeography of Sri Lanka
}

\author{
P. Wickramagamage*
}

Department of Geography, University of Peradeniya, Peradeniya, Sri Lanka.

\author{
Received: 20/11/2016; Accepted: 18/03/2017
}

\begin{abstract}
The area referred to as the 'Central Highlands of Sri Lanka', despite being the venue of a thin scatter of 'Stone Age' human settlements was sparsely populated by man throughout the island's 'Pre-Modern Era', and much of it, especially at its higher elevations remaining under primeval forest cover. In late medieval times when this highland area became a part of the 'Kandyan Kingdom', its forest-clad localities, except those that were appurtenant to village settlement ecology, tended to be strictly protected under royal decree.
\end{abstract}

The cultivation of coffee on large areas of land 'plantations' or 'estates' -commenced as a major economic enterprise after the establishment of British rule over the island in the early 19th century. This invariably entailed the extensive clearing of forests. The 'Ferguson map' that depicts the coffee estates that existed in 1863 and 1880 provides valuable information about the distribution of coffee plantations.

The present study is a product of an attempt to determine the location and the extent of coffee plantations in relation to vegetation zones, administrative districts, and river basins of the Central Highlands. It indicates, inter alia, the main plantation area in the Upper Mahaveli catchment, and in the sub-montane zone. The second largest extent was in the Kelani Basin. Clearing of forests led to erosion of hillslopes, siltation of riverbeds and the low-lying areas, particularly in these two river basins. Within a period of 50 years the landscape of a large part of the Central Highlands was transformed from forest-covered hills to a landscape dominated by plantations. This process caused irreparable damage to the biodiversity of the montane and submontane areas of Sri Lanka.Keywords: endemism, evolutionary stable unit, mammal subspecies, habitat quality, ecological niche, mammalian evolution.

Keywords: Prehistory, colonial, deforestation, coffee, montane, sub-montane.

\section{INTRODUCTION}

From a diastrophic perspective the island of Sri Lanka lies in the Indian plate in close proximity to peninsula India. Sri Lanka and India share the same continental shelf and the former is therefore a continental or a shelf island. Unlike oceanic islands, Sri Lanka has had on and off connection to the subcontinent allowing the dispersal of organisms in the geological past. Western Ghats and Sri Lanka are designated as a single biogeographical unit which first identified by Wallace (1876). However, as noted in a recent study since the moist Western Ghats and the Wet Zone of Sri Lanka are separated by a dry lowland plain, it might have acted as a barrier to dispersal of plants and animals (Bossuyt et al., 2004). It should also be noted that the climate of this area may not have been similar to what it is today during the last glacial period. Based on the present climate, the authors referred to above conclude that the Wet Zone of Sri Lanka could be considered as an insular biogeographic region with its distinctive characteristics.

The island's elevation ranges from the sea level to over $2,500 \mathrm{~m}$, with a range of microclimatic sub-regions. Associated with these microclimatic regions are diverse ecosystems. The highlands were endowed with extensive forest cover with limited interference by humans up to the colonial period. The highland forests are divided into submontane (1000-1500) and montane ( $>1500 \mathrm{~m})$ forest types. In addition, there are two types of grasslands known as Dry Patana and Wet Patana. The former is found in most climatic zones, whereas the latter is confined to the wet areas.

The status of forest cover at the time of British annexation of the Kandyan Kingdom and the events thereafter could be traced from many literary sources. These information sources include contemporary writings by explorers, environmentalists, and visitors, etc., statistics compiled by the colonial rulers, and cartographic products. Although proper mapping of the island started at the beginning of the $20^{\text {th }}$ century, two map compilations of the coffee estates based on survey plans are available. These maps provide very precise information about the extent and location of the individual estates, in the highlands of Sri Lanka. The impact of human interventions can also be gleaned from reports prepared by various commissions appointed by the colonial administration to address serious environmental consequences of plantation agriculture and environmental concerns highlighted by environmentalists. This study analyses the information available from a representative sample of these different sources to understand the scale of deforestation in the highlands after the fall of the Kandyan Kingdom in 1815 and up to the end of the coffee industry in 1880 s.

In order to determine the ecological impact of colonial rule, it is imperative that we establish a baseline by reviewing the information relating to human activity in this region during prehistoric and historic periods, which preceded the colonial experiment. This paper is a reinterpretation of all the available information to evaluate 
the process of deforestation and its impact on Sri Lanka. Another important aspect of ecological impact of colonial rule is the introduction of new species to the highlands. This has been dealt with in detail in other works (Webb, 2002).

\section{DATA AND METHODOLOGY}

The data and information used in this analysis include secondary data available in the form of historical maps, statistics, government records and textual sources. Based on the block out plans prepared for land sales, a map was compiled and published by the Ferguson Ceylon Observer Office (1880). This map shows the coffee estates that existed in 1863, and those developed between 1863 and 1880. The scale of this map is one inch to two miles. Another map based on the surveys carried out for land alienation to planters was compiled by Arrowsmith in 1862 , which is commonly known as the Fraser's Map. Both maps depict estate boundaries, but the Frazer's map also carries the names of the estates. Several researchers have made references to these maps (Baranage, 1983, Roberts, 1970), but no one has studied them quantitatively in relation to the location of coffee estates in different environmental and administrative settings. In the absence of any other sources of locational information on the coffee estates of Sri Lanka, the Ferguson map provides invaluable information on the spread of coffee plantations in Sri Lanka. As this map does not have the coordinate grid printed on it, geo-referencing of the map was done based on modern 1:50,000 maps. Additional data were extracted from Sessional Papers of the Legislative Council of Ceylon, and Blue Books of the $19^{\text {th }}$ century. These sources provide data on land sales, cultivated area, etc. The contemporary writings also helped to determine the extent of deforestation in $19^{\text {th }}$ century Ceylon (Sri Lanka). From the georeferenced image of the coffee plantations map, the estate boundaries were digitized and the extent of each estate was calculated. The map shows coffee estates as belonging to two time periods, 1830 to 1863 and 1863 to1880. It depicts all the coffee estates that existed at that time, except 38 estate properties covering approximately 3,159 ha (7806 acres) or $2.6 \%$ of the total area that could not be accounted for at the time of map compilation because their location could not be determined.

The map of the coffee estates was overlaid with elevation zones, district boundaries and river basin boundaries. A digital elevation model (DEM) of Sri Lanka was created from elevation data from the 1:50,000 maps and the boundaries of montane and sub-montane zones were extracted from the DEM. The river basin boundaries were also updated using the same DEM. The area under coffee was estimated by district, elevation (vegetation) zone, and river basins. This gives a more accurate picture of the extent of land above the $1000 \mathrm{~m}$ elevation that came under coffee cultivation during the periods under study and, consequently, the extent and rapid scale of deforestation within each subzone.

\section{THE MONTANE AND SUB-MONTANE AREA}

The montane and sub-montane areas are defined on the basis of the elevation alone. The area within $1000=1500$ $\mathrm{m}$ is the sub-montane and above $1500 \mathrm{~m}$ is_montane. The total extents of the sub-montane and montane regions are 176,455 ha and 80,163 ha respectively. Both these units fall within the Wet and Intermediate climatic zones. The montane and sub-montane elevation zones act as important upper catchment areas of the major rivers of Sri Lanka (Figure 1). The highest elevation of the montane zone is $2,534 \mathrm{~m}$ at Pidurutalagala peak. Since elevation is decidedly the most important determinant of the island's climate and water resources, it is important to note that rains brought by the two monsoons have much to do with the position of the small but very important highlands in the south central part of the island.

The topographic variation of this small area is also a factor in the great variability of the climate and ecology of the island. Figure 2 is a plot of the elevation $v s$. the land area above that elevation, and it shows that the area above $500 \mathrm{~m}$ contour is only just over $9 \%$ of the total area of the island. The extent of the montane and sub-montane areas combined is only about $4 \%$ of the total land area of the island. The agroecological diversity of the region is shown by the presence of 22 agroecological regions within the area above $1000 \mathrm{~m}$ contour (Punyawardene et al., 2003).

\section{RESULTS AND DISCUSSION}

\section{Status of the Pre-colonial Forest Cover of the Highlands}

The available evidence shows that the montane and submontane forests of Sri Lanka were not free of human interference in ancient times, but the impact of these interventions would have been rather limited to clearing of small patches of forest at a time. The earliest evidence of human presence in the highlands goes beyond the Last Glacial Maximum (LGM) about 18,500 years ago. The distribution of pre-historic habitation sites, can be used as an indicator of some form of deforestation. A map was compiled based on the pre-historic sites mentioned in the literature (Figure 3). This map shows that pre-historic habitation sites were spread over the whole of Sri Lanka including the highlands. These sites have been dated from 125,000 BP (Bundala in the South coast) to the historic period (Deraniyagala, 1992).

An alternating sequence of dry and humid phases of variable duration have been recorded by Premathilaka and Risberg (2003) at Horton Plains. The humid phases were associated with warmer periods and dry/arid conditions with the cooler periods. Formation of a stoneline (a subsurface gravel horizon) in the Horton Plains and deposition of fine sand and silt over it suggest high rates of fluvial erosion followed by wind action depositing fine sands and silt (Wickramagamage, 1995). The effect of climate change on vegetation at high elevations is evident from the pollen record studied by Premathilake and Risberg (2003) and Premathilake (2012). Sediment cores from a marshy area in Horton Plains show a history of vegetation change associated with dry/arid and humid climate phases from 


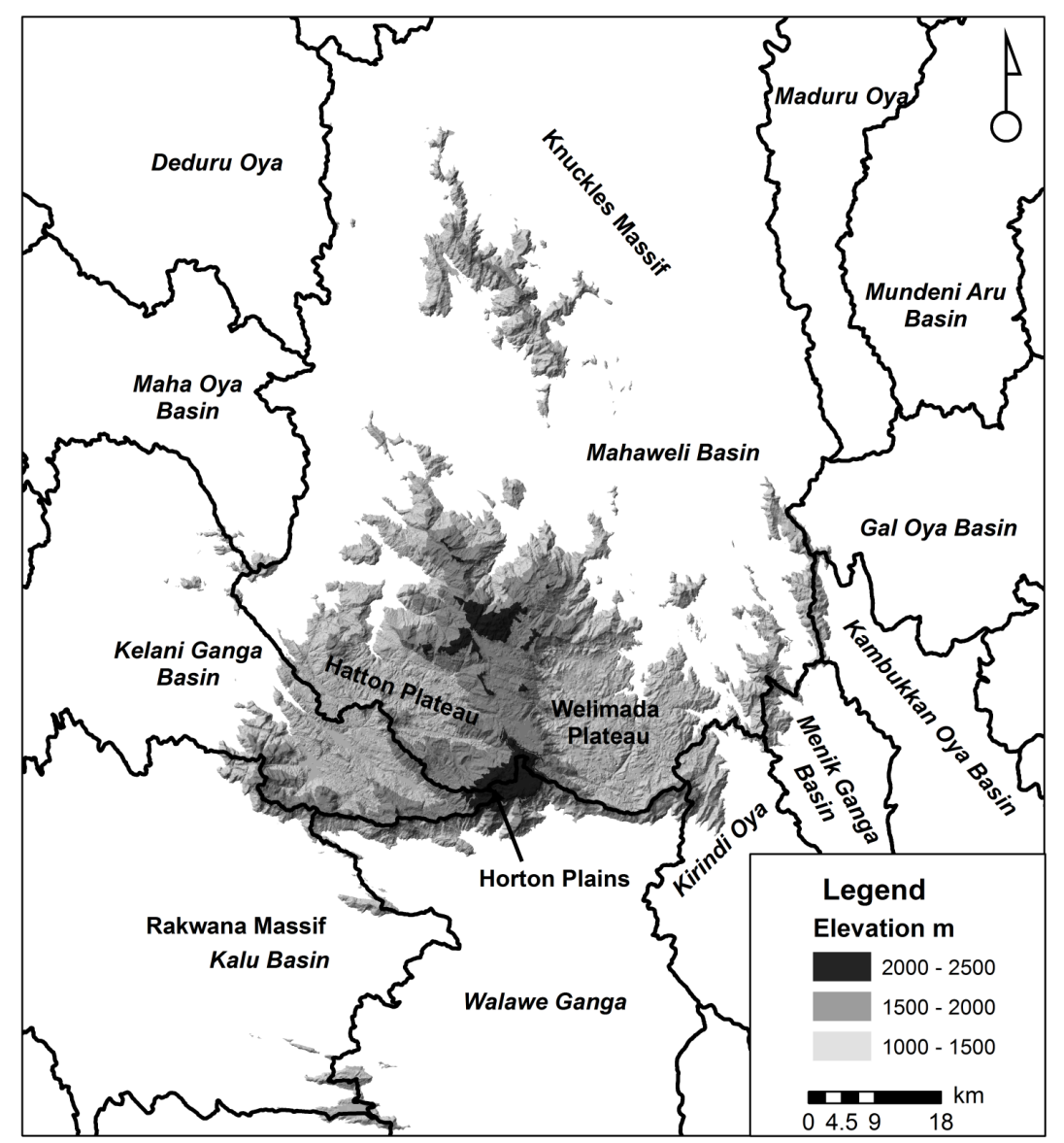

Figure 1: Montane and sub-montane elevation regions of the hill country of Sri Lanka.

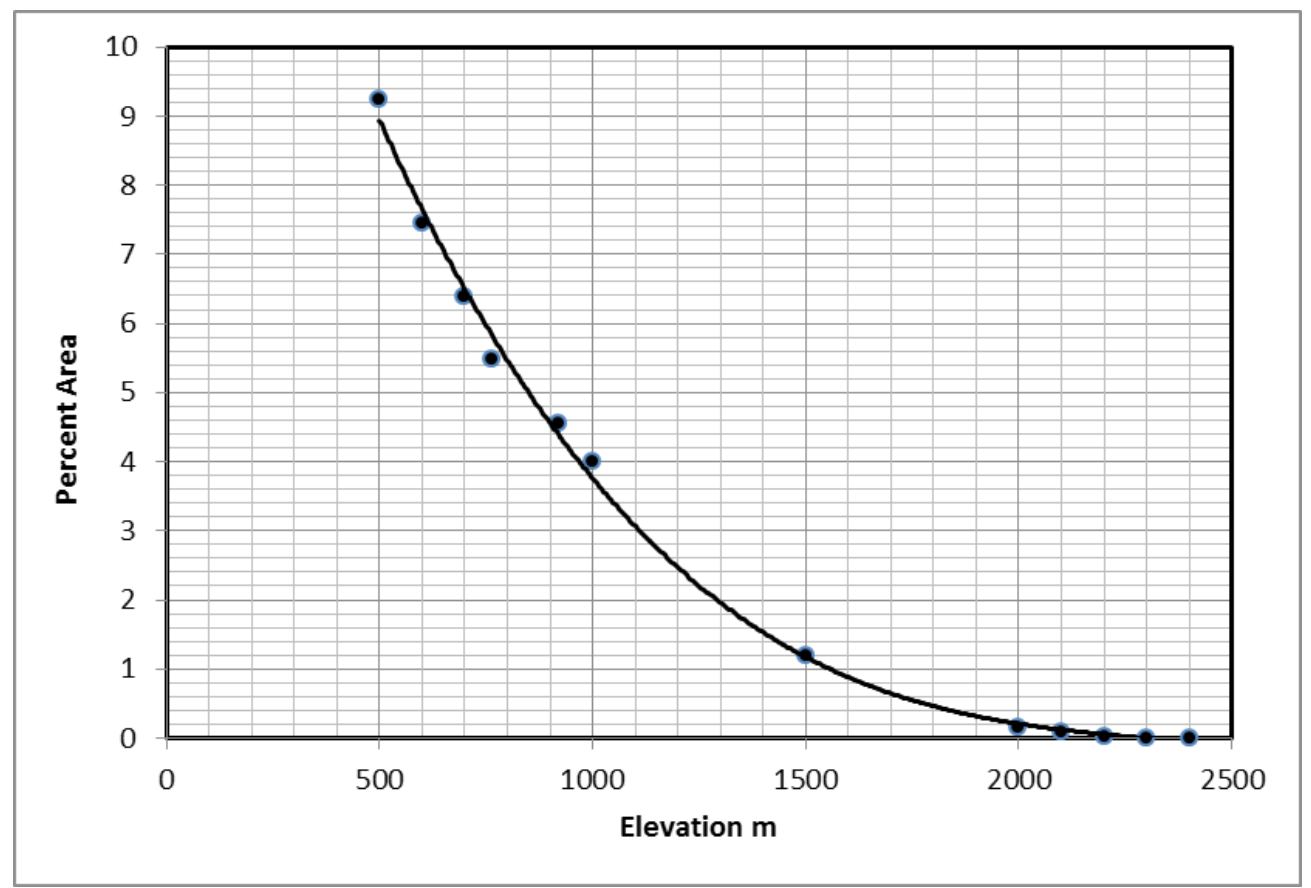

Figure 2: Percentage area of the island above selected elevations. 


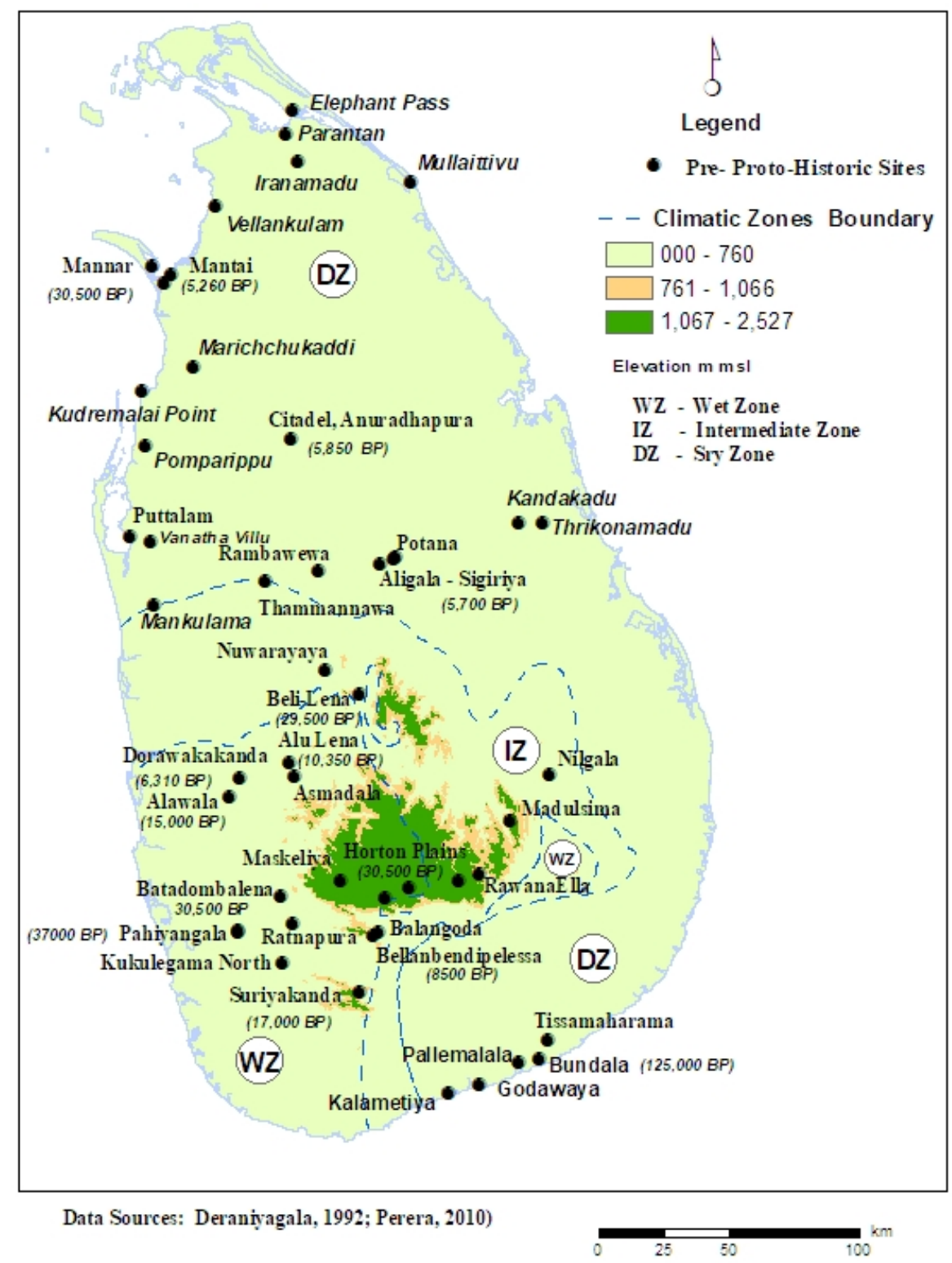

Figure 3: Pre- and Proto-historic habitation sites of Sri Lanka.

about 24,200 BP to about 600 BP (Premathilake, 2006). Premathilaka concluded that the humans were absent from the earliest period up to about 18,500 BP but continued to occupy the subsequent layers. The stone-age humans were the first to modify the montane and sub-montane forests of Sri Lanka. However, some sites in the Horton Plains are dated to 30,500 BP (Deraniyagala, 1992). Impacts of stone-age man had on the forests can only be speculated. Perera (1972) reckons that there is a similarity between the stone-age cultures in Sri Lanka and similar cultures in the present-day Papua New Guinea. The forests cleared by the latter for agriculture and to protect habitation sites from wild animals ended up as grasslands. Based on this evidence, Perera (1972) concludes that the grasslands in the hill country of Sri Lanka may have been a product of burning of forests during stone-age. It is well known that armed with fire stone-age cultures were quite capable of destroying the forest cover. At the time of British annexation, the vegetation of the highlands was forests and grasslands.
The historic period is characterized by the development of the hydraulic civilization in the lowland Dry Zone, while the highlands remained relatively free of human activity. By overcoming the water shortage, agriculture spread into every nook and corner of the Dry Zone (except perhaps Jaffna Peninsula and the small islands) as evident from the distribution of ancient tanks. The lowland Dry Zone thus became the cradle of island's hydraulic civilization. After the collapse of the Dry Zone civilization, the population shifted to the lower and middle Wet Zone highlands, but most of the settlements were confined to the lower valleys of the Mahaweli River and its tributaries (Wimaladharma, 1977). Distribution of human settlements during the Kandyan period after the demographic shift towards the highlands can be used as indirect evidence of the status of the forest cover in the montane and sub-montane regions during that period:

- $\quad$ The distribution pattern of human settlements in the Kandyan period: Based on historical sources, several authors (Perera, 1972; Wimaladharma, 1977; Webb, 
2002; Duncan, 2007) concluded that up to the end of the Kandyan Period most of the population of the island lived at elevations below the 762-1066m (2500-3500 feet) contour, with only exception being a few settlements such as Kotagepitiya (Roberts, 1970) and Ramboda in Kotmale, Bambaragala and Rabukwella in Dumbara valley, etc. that were located above this elevation. Moreover, the few villages that existed at elevations above $1000 \mathrm{~m}$ contour did not have a large population. According to Laurie (1896), the Kotagepitiya village, for instance, had a population of only 230 persons in 1881 .

- Population Census Data: The first-ever census of the Kandyan provinces taken in 1821 reveals that the total population in the region was only 250,000 including the indigenous, European and other Asian peoples. The second census in 1827 covering an area of 36,977 square $\mathrm{km}$ gives the total population in the region as 288,000 people. This amounts to a population density of about 8 persons per square $\mathrm{km}$ (Webb, 2002). This level of population density would not have had a serious impact on the forest cover of the Highlands above $1000 \mathrm{~m}$.

- Contemporary Writings: A number of literary sources of the European writers of the $19^{\text {th }}$ century refer to the extent of forest cover in the island in general and in the hill country in particular. The writers, such as Emerson Tennent, Capper, etc., provide a glimpse of the state of the forest cover of the island in the $19^{\text {th }}$ century (Capper, 1849; Tennent, 1860). Tennent observed that pre-colonial Sri Lanka was well endowed with forests while Capper, writing in the middle of the 19th century, claimed that a great part of the Kandyan Hills up to Bintenne was covered with forests (Capper, 1849). Although there may be some exaggeration in these accounts, they nevertheless indicate that the forest cover in the hill country was still substantial in extent before the start of the second and more extensive expansion of coffee plantations after 1850 .

- Preservation of natural forests in the highlands during the Kandyan period can be attributed to the precolonial forestry policy which was largely dictated by security concerns of the Kandyan Kings rather than environmental considerations. The Kandyan Kings used forests among other natural obstacles as fortification against potential invaders from the lowlands. Forest areas were also useful hiding places when the invaders were successful in breaching the fortifications (Vincent, 1882). For the administration of forests, Kandyan kings divided the forests into three categories (Wimaladharma, 1977):

1. Mukalana or Village Forest below 1000m: All Kandyan villages had forests surrounding them and these forests separated villages from each other. They were commonly owned and used by villagers for chena (shifting) cultivation.

2. King's High Forest: These forests were more strictly controlled by the king. For the purpose of forest administration, they were divided into two categories:

a. Rajasanthaka-kele or Crown Forests: Only grazing, collection of firewood, honey, timber, etc. were permitted. b. Thahanci-kele or Forbidden Forests which were at the highest elevations and covered the steepest slopes and hill tops. They were out of bounds to the people, except for those who were assigned to police them.

3. Forest barrier around the Kingdom: Vincent (1882) reports that there was a $40-60 \mathrm{~km}$ wide forest belt right round the Kingdom of Kandy and it was well guarded. The forests (wana durga or forest barrier) were one of the three Durgas or barriers that were employed as fortification to protect the Kandyan Kingdom from invaders from the lowlands, giri durga (mountain barrier) and jala durga (water barrier) being the other two natural of barriers. The key role that the wana durga played in protecting the Kingdom from invaders meant that strict protection of forests was absolutely essential.

During the Kandyan period, only the communal forests were allowed to be cleared for agriculture. Even those lands were left under fallow after cultivation for a few seasons and the same plot of land was not revisited for about 15-25 years (Duncan, 2007) in order for the soils to regain the lost productivity.

Official Statistics: The Ceylon Blue Book of 1881 estimates the forest cover in the wet and dry zones of Sri Lanka at $71 \%$ and $91 \%$ respectively. This is because the extent of land cleared for coffee planting was relatively minor when the whole Wet Zone was taken into account. But that extent is a significant proportion of the montane/ sub-montane zone areas, which is only a small area of 256,600 ha.

Archaeological Evidence during the Historical Period: Recent archaeological studies have laid bare evidence of steel making in the Samanala Wewa area, where numerous iron smelting technology sites have been discovered by archaeologists (Juleff, 1998). According to Juleff, these iron smelting operations were functioning for a time span of 15 centuries, from 3 rd century BC to about $12^{\text {th }}$ century AD. The west-facing slopes receive ample wind flows during the southwest monsoon period. Charcoal that was used as a fuel for smelting came predominantly from three tree species, maran (Syzygium zeylanicum), pathberiya (Syzygium spathulatum) and damba (Syzygium gardneri). This activity would not have contributed to large-scale deforestation. Despite these intrusions by man into the hill country during the historical period, the area above the $1000 \mathrm{~m}$ elevation remained primarily under forest or grass cover up to the British colonial period.

\section{Forests Conversion to Coffee Plantations}

The colonial period marks a watershed in the vegetation history of the highlands. Immediately after the annexation of the Highlands by the British at the beginning of the $19^{\text {th }}$ century, commercial plantation agriculture was introduced to the highlands. The early planters did not pay any attention to the need of soil conservation on hill slopes and indiscriminate use of sloping lands for agriculture led to rapid degradation of soil and loss of productivity of land (Wickramagamage, 1990). 
The process of deforestation in the hill country began only about 15 years after the conquest of the Kandyan Kingdom in 1815 by the British colonialists. But it did not take off in a big way until about 1840 which marked the beginning of the first wave of land alienation as can be seen from Figure 4. Impetus for this change came from several sources. The collapse of the coffee industry in the West Indies after the abolition of slavery, equalization of import duty on West Indies and Ceylonese (Sri Lankan) coffee in Britain, and the appropriation of 'unoccupied' land in the island by the enactment of the Crown Lands Ordinance of 1840 were the main factors fuelling the first wave of land purchases in the island (Duncan, 2007). This however did not last long. Developments in the coffee industry elsewhere adversely affected the coffee industry in Sri Lanka. The lowering of import duty on Brazilian and Javanese coffee and the economic depression in Europe led to the demise of the Ceylonese coffee industry resulting in a drop in the sale of land in the colony to a few hundred hectares per year from more than 1000 ha per year previously. This reprieve for the island's forest cover ended however with another wave of land sales marking the second coffee boom, which lasted for the next 20-25 years with the area under coffee reaching a peak in 1875 . Although all the land purchased was not cleared for coffee growing, the land sales figures show the scale of the operation.

\section{Land Sales in $19^{\text {th }}$ Century}

Land sales statistics are a reliable source of information about the extent of land cleared either for coffee cultivation or for other uses. The annual land sales progressed as three waves reflecting the rise and fall of coffee industry in the highlands of Sri Lanka and the introduction of tea cultivation (Figure 4). The first two waves in land sales represent the coffee booms in the island. The drop in the price of coffee in Europe led to the abandoning of about 10 per cent of estates in Ceylon (Duncan, 2007) and first massive drop in land sales around 1850 as seen in Figure 4. Between 1833 and 1850 a total of over 121,000 ha was sold to prospective planters. Technological innovations in agriculture, improvement in coffee prices and the development of the Colombo-Kandy Railway contributed to the second coffee boom in the 1850s, 60s, and 70s .
Between 1851 and 1880, a total of about 350,000 ha was sold for plantation agriculture.

The construction of the Colombo-Kandy Railway in fact reduced transportation costs between 60-75\% (Duncan, 2007). The cultivation of coffee received another boost during this period with the arrival of the plantation companies along with foreign capital and planters from the West Indies. Some investment was channelled through Agency Houses which started developing and managing coffee estates. The year 1878 saw the extent of ,the coffee plantations reaching its highest point $(111,292$ ha Webb, 2002).

Small-scale coffee planting was undertaken by Kandyan farmers as well. The extent of forest clearance by Kandyan farmers between 1812 and 1845, as estimated by Vanden Drieson (1953), was 42,614 ha. But this figure was arrived at based on coffee export figures and taking the coffee yield as five hundred weight per acre. Webb (2002) considers that the yield per acre used for this estimate is too high and the extent of land under coffee cultivation should therefore be higher. It is also noteworthy that up to about 1830 , most of the coffee was grown in home gardens. Taking these into consideration, the impact of native coffee cultivation on the forest cover can be considered to be insignificant.

Even before the coffee boom reached its zenith, the early signs of its ultimate demise began to appear in the form of a coffee rust known as Hemileia vastatrix in 1868 in the young plantations of the Madulsima area in Badulla district, and its rapid spread decimated the coffee plantations in the island leaving only a few hectares of working coffee estates by $1880 \mathrm{~s}$. The destruction of coffee plantations by the coffee rust led to the clearing of more forests for new plantations at even higher elevations.

The decimation in coffee plantations also triggered a drop in the demand for land once again ending the second wave of land sales from 1875 to about 1890 . Between 1830 and 1866, 253,429 ha of land were sold, out of which 182,113 ha were bought by Europeans (Ferguson, 186668). Of the lands that the Europeans bought, $72 \%$ were hill forests whereas most of the land purchased by the locals were in the lowlands for coconut cultivation. Between

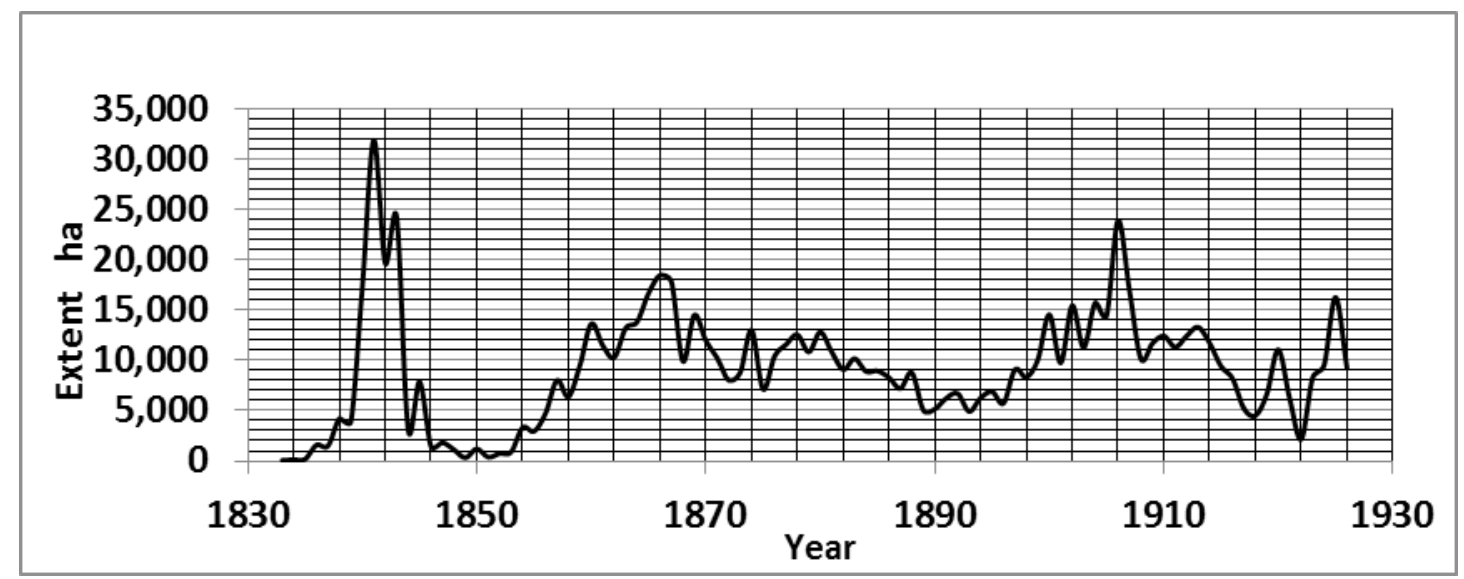

Figure 4: Extent of sale of crown lands in Ceylon during the British Rule between 1833 and 1926. Land sales peaks in 1841, 1866 and 1906. 


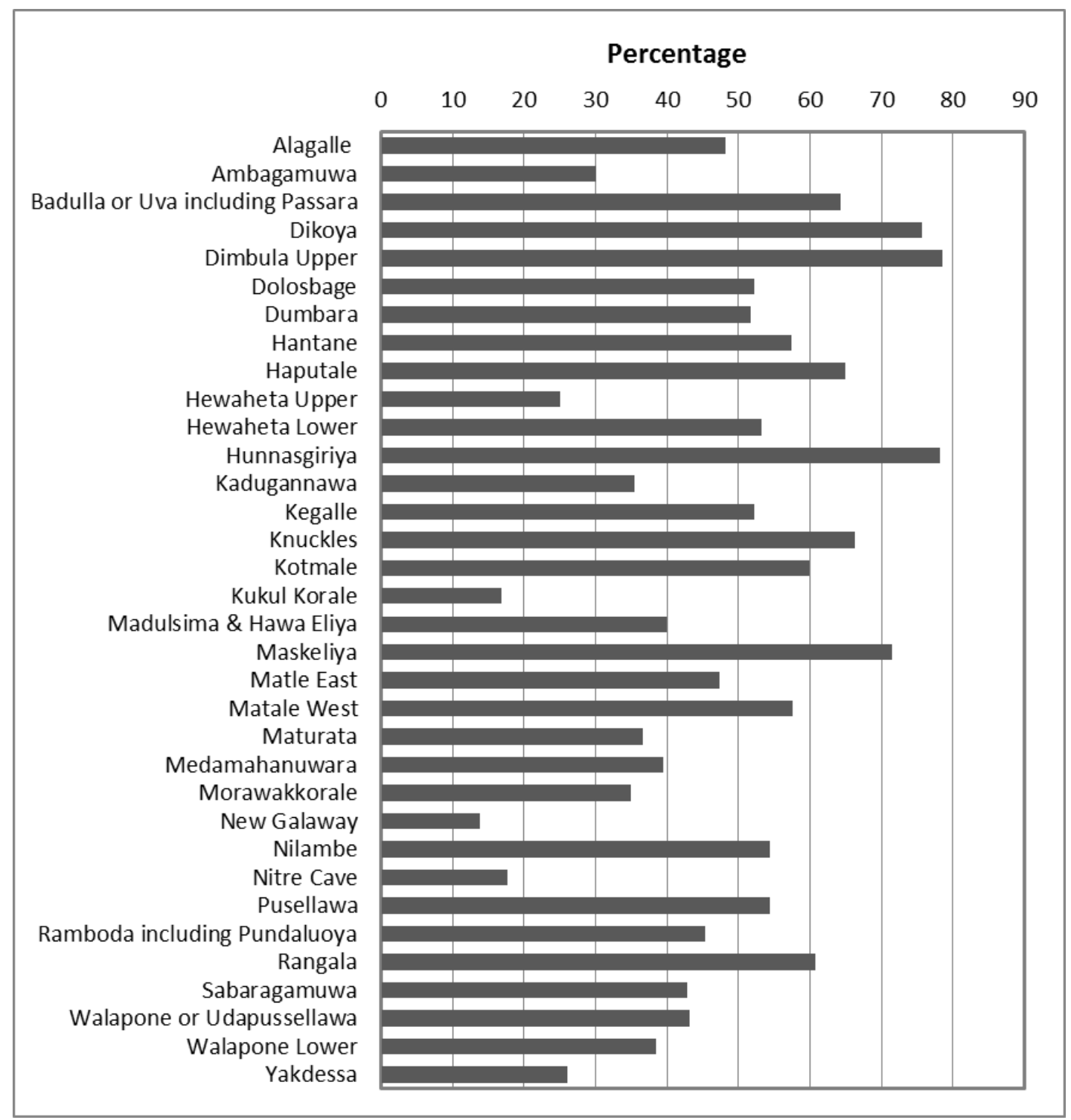

Figure 5: Cultivated area in 1875 as percentage of the total estate lands.

1870 and 1879 , a further 161,878 ha of crown lands were sold, of which 40,469 ha were devoted to coffee cultivation (Ferguson, 1893).

All the land purchased by the planters however was not cleared for coffee cultivation. About a quarter of the land purchased by Europeans was later abandoned. This is very clear from the data available on the extent of land of some estates and the area cultivated as given in Figure 5. There is a large variation among estates in terms of the area that was placed under cultivation. Of the 34 estates for which data are available, the cultivated area averages approximately $48 \%$. However, the remaining forest lands of the estates were used for the extraction of firewood for curing of coffee. All estates therefore would have adhered to this practice of keeping some forest areas as sources of firewood.

The statistical data on the extent sold and cultivated alone do not give us a clear picture of the devastation caused to the island's mountain ecology. The Ferguson map provides valuable information about the extent as well as the location of the coffee estates, and thus the areas where the actual deforestation took place. Distribution of coffee estates is discussed here with respect to district, elevation, and the river basins (Figure 6).

\section{Coffee Estates in Former Forests}

The map of coffee estates prepared by J. Hodden and Co. for Ferguson Ceylon Observer Office provides information about the geographic distribution of the coffee estates in Sri Lanka in 1863 and 1880 (Figure 6). According to this map, the area that was under coffee was distributed all over the hill country covering about $44 \%$ of the montane and sub-montane forest areas, with a total area of 222,773 ha of coffee estates distributed in the nine hill country districts. New forest lands were cleared after 1863 in the planting districts and new plantations were started in Matara district also. 


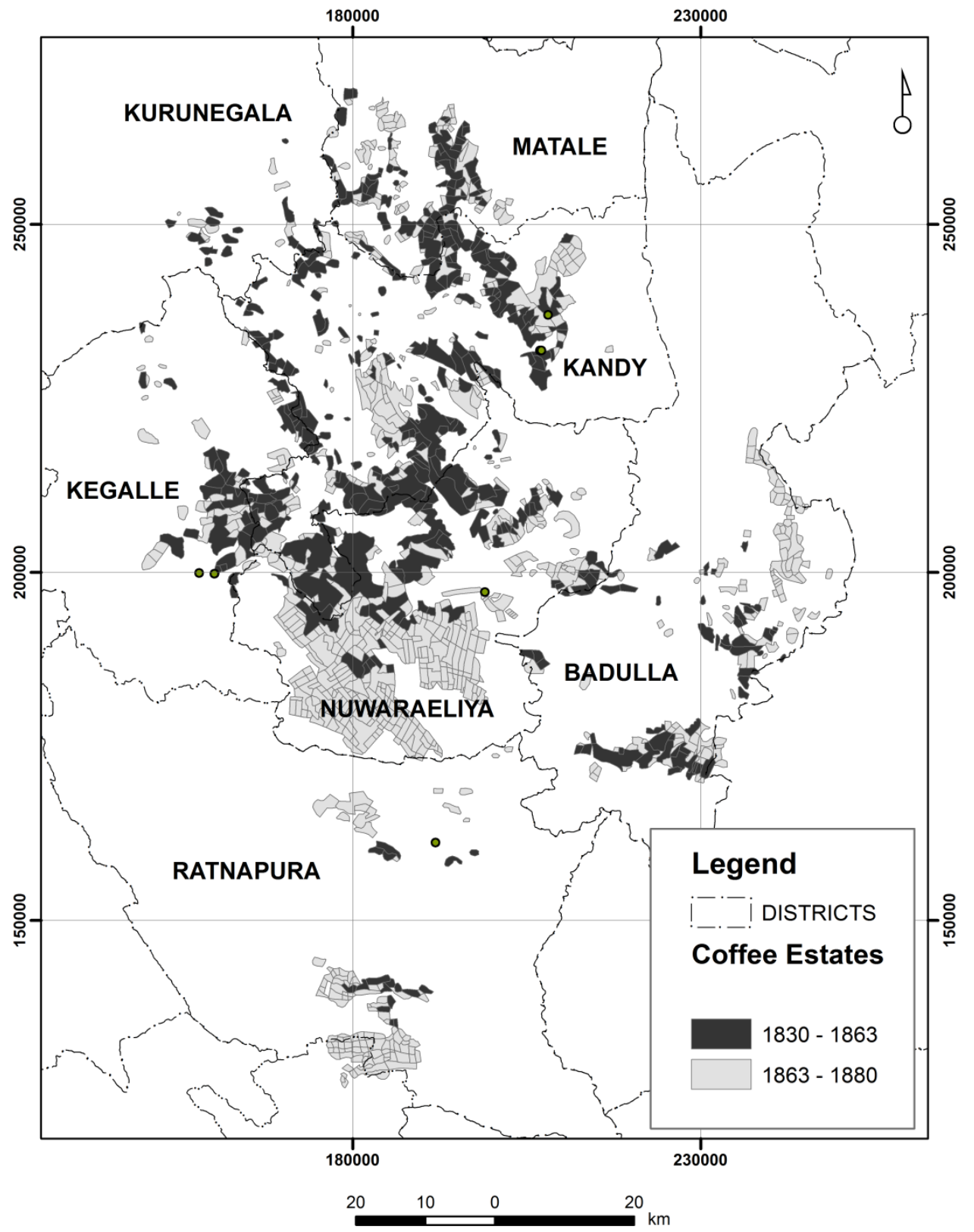

Figure 6: Spread of coffee estates in the central highlands from 1830 to 1880. 
Table 1: Coffee estates by elevation zone and time period (area in ha).

\begin{tabular}{|c|c|c|c|c|}
\hline Elevation (m) & $1830-1863$ & $1863-1880$ & Total (ha) & Zone \\
\hline $500-1000$ & 40,926 & 39,745 & 80,671 & Lowland \\
\hline $1000-1500$ & 39,514 & 53,345 & 92,859 & Sub-montane \\
\hline$>1500$ & 5,989 & 14,902 & 19,966 & Montane \\
\hline Total & 86,429 & 107,992 & 194,421 & All \\
\hline
\end{tabular}

Source: Based on Ferguson's map

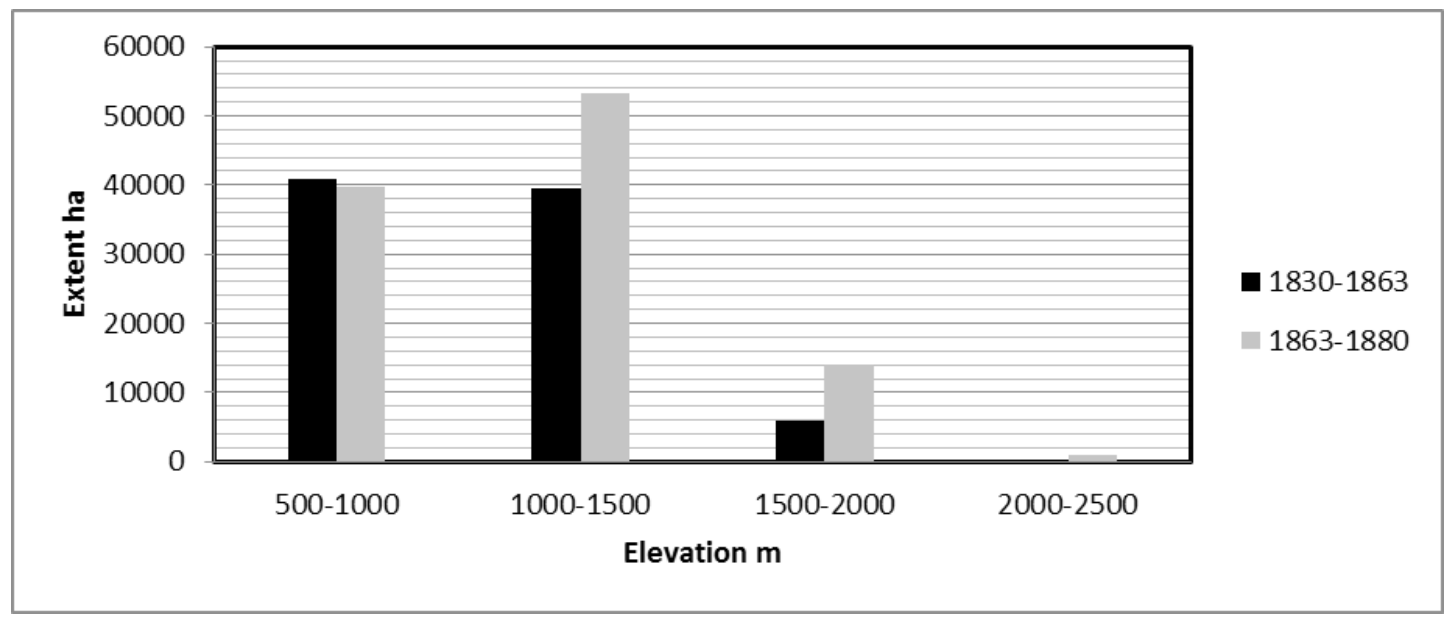

Figure 7: Extents of coffee estates by elevation zone as stood in the years 1863 and 1880 .

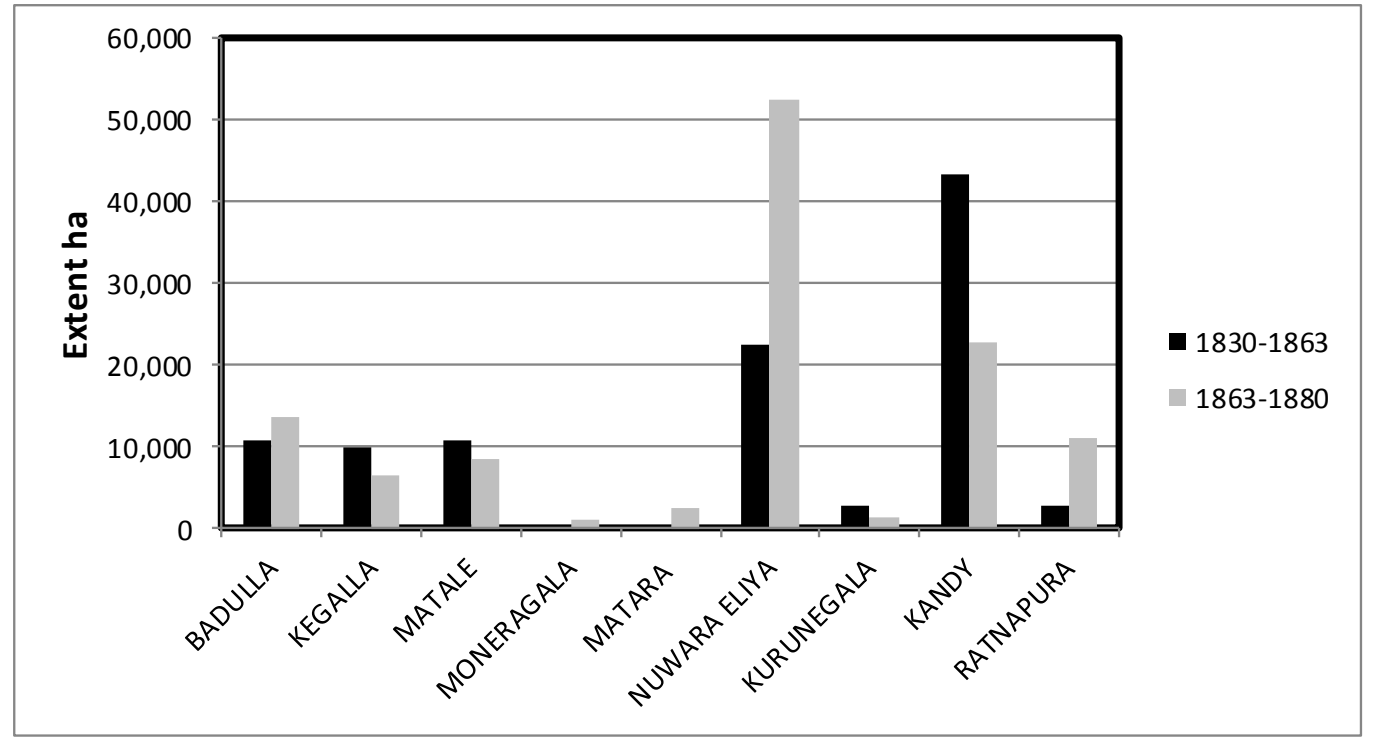

Figure 8: Distribution of coffee estates in the highlands by districts from 1830 to 1880 .

As can be seen from Table 1 and Figure 7, the extent under coffee substantially increased after 1863 in both submontane and montane areas, while a slight decline recorded in the area below $1000 \mathrm{~m}$ contour. The largest increase is in the sub-montane area. Thus the percentage area cleared for coffee in the montane and sub-montane areas reached $26 \%$ and $53 \%$ of the total land areas respectively by 1880 (Table 1 and Figure 7). The main driver of the spread of coffee planting into the higher elevations was the leaf disease, Hemileia vastatrix that afflicted the estates at lower elevations. All plantations were abandoned by the 1880 s and most of the land under coffee was converted to cinchona or tea. Thus, coffee, the first plantation crop introduced to Sri Lanka, was responsible for the deforestation of a large part of the highlands.

The difficulty in access and the belief that high elevations were not suitable for the coffee plant have contributed to the lower penetration initially into the montane zone. This were to change in $1860 \mathrm{~s}$. Construction of roads and railways later would have allowed greater access to the 


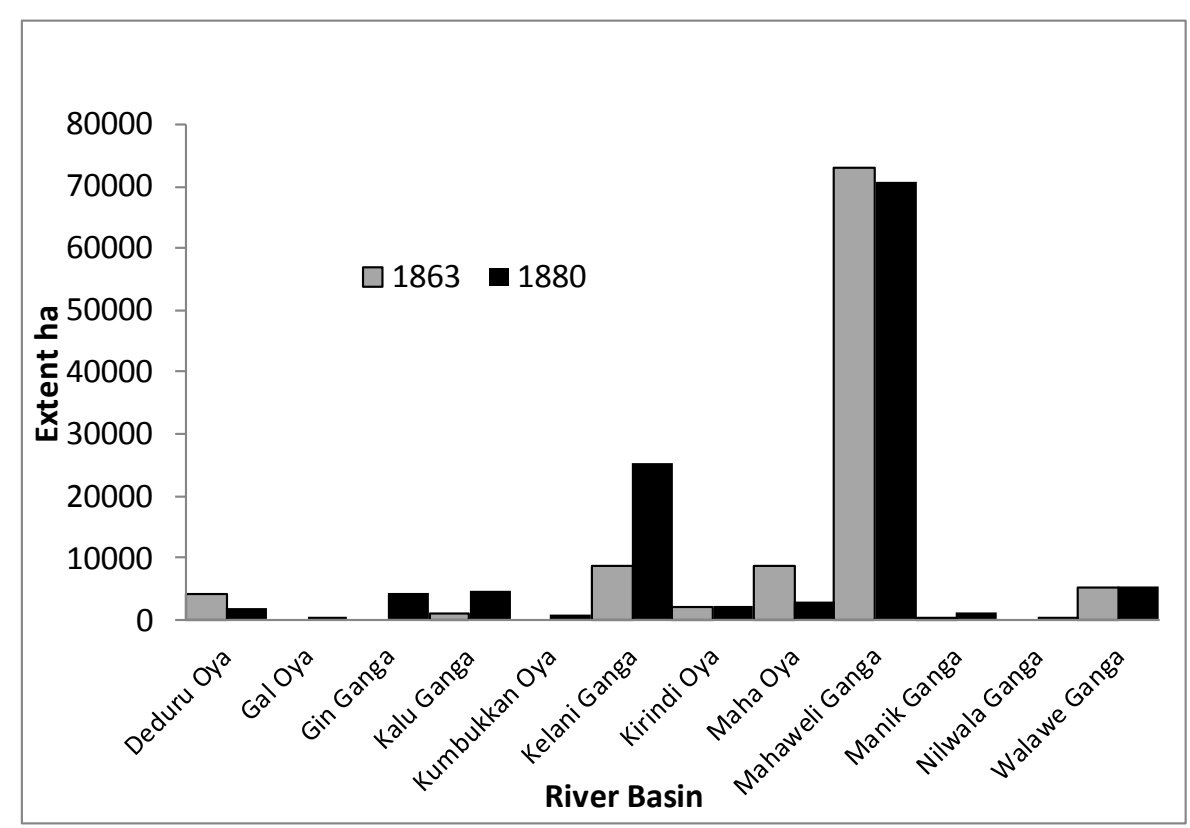

Figure 9: Coffee cultivated area by river basins in Sri Lanka during the British period.

Table 2: District-wise distribution of coffee plantations (ha).

\begin{tabular}{lrrr}
\hline District & $\mathbf{1 8 3 0 - 1 8 6 3}$ & $\mathbf{1 8 6 3 - 8 0}$ & Total \\
\hline Kurunegala & 2675.3 & $1,421.5$ & 4096.8 \\
\hline Kandy & $43,240.9$ & $22,765.9$ & 66006.9 \\
\hline Kegalle & $9,916.5$ & $6,546.2$ & 16462.7 \\
\hline Moneragala & 233.0 & 969.5 & 1202.5 \\
\hline Badulla & $10,748.8$ & $13,550.2$ & 24299.0 \\
\hline Matara & 0 & $2,553.9$ & 2553.9 \\
\hline Ratnapura & $2,717.9$ & $10,297.8$ & 13015.7 \\
\hline Nuwara Eliya & $22,604.2$ & $52,617.4$ & 75221.7 \\
\hline Matale & $10,727.9$ & $8,556.8$ & 19284.7 \\
\hline Total & $\mathbf{1 0 2 , 8 6 4 . 5}$ & $\mathbf{1 1 9 , 2 7 9 . 2}$ & $\mathbf{2 2 2 , 1 4 3 . 9}$ \\
\hline
\end{tabular}

remote areas of the hill country. Another incentive was to try out new lands at higher elevations.

One important decision taken in the 1870 s by the colonial office in London put an end to sale of land above $1524 \mathrm{~m}$ (5000 feet), but clearing of forests above this elevation continued even after that because the land already bought did not come under this law. This banning order and the declaration of certain areas as forest reserves protected some of the remaining forests after the $1880 \mathrm{~s}$. At the same time, narrow strips of land on either side of the river channels were also declared as stream reservations.

The district-wise distribution of coffee estates given in Table 2. The largest extent was in the Kandy district while the Nuwara Eliya district came second. However, after 1863, most of the expansion took place in the Nuwara Eliya District (highest elevations), relegating Kandy to the second place. The Ratnapura, Nuwara Eliya and Badulla districts had larger extents under coffee in the second phase than in the first. All hill country districts experienced deforestation during the coffee period (Table 2, Figure 8).

The effect of clearing of forests in the upper catchment areas were severe. Coffee was cultivated in 12 river basins, most of which was in what is considered hydrologically the most sensitive upper catchment areas (Figure 9). By far the largest area of coffee estates was in the Mahaweli basin, where 143,609 ha were cultivated, which was about 64 per cent of all coffee estates. The second largest area was in the Kelani basin with about 15 per cent. The Maha Oya and Walawe basins had about 5 per cent each while all other basins had below 3 per cent each of coffee cultivations. Thus the Mahaweli and Kelani were the most significantly affected river catchments. The extents of new plantations in the Kelani, Kalu and Gin basins are significantly higher in the second phase than in the first phase. However, the 
largest area of new plantations in the second phase was in the Mahaweli Basin.

\section{Effect of Deforestation}

The multitude of impacts that accrued from the clearing of highland forests for coffee plantations can be classified as both direct and indirect. The direct impacts are the loss of biodiversity and habitats. The indirect impacts are degradation of soil through erosion and retardation of soil development, siltation of low-lying areas and river beds, and the increase in landslides and floods. The words of George Gardner, the Superintendent of the Royal Botanical Gardens, Peradeniya, succinctly described the direct impacts of the clearing of forests for plantation agriculture as early as 1843 :

"Of late large tracts of the country have been cleared of the virgin forests by which they covered, from the rapid spread of cultivation; and as this is likely to go on to a great extent there can be no doubt that many of those trees which are peculiar to the Island, and local in the range, will long become extinct; and the Botanists of future times will look in vain for many of those species which their predecessors had recorded in the annals of science as natives of the Island. This is no idle speculation, such having already occurred in other countries." (Qtd. in Webb, 2002)

The devastation caused to forests is also summarized in the Encyclopaedia of Ceylon (1902):

"The summits of the highest ridges are clothed with verdure, and along their base, in the beautiful valleys which intersect them in every direction, the slopes were still within the last few years covered with forests of gigantic and valuable trees, which have now disappeared under the axe of the planter, who has felled and burnt the timber on all the finest slopes at an elevation of 2000 to 4500 feet, and converted the hillsides into highly-cultivated coffee estates."

The indirect effects are equally grave as can be seen from the reports of G.H.K. Thwaites, Director of the Royal Botanical Gardens, Peradeniya, and many commission reports on the subject. According to Bastianpillai (1968), Thwaites feared soil erosion, decreased rainfall and eventual land desiccation unless the planters' activity was regulated. The forests in the highlands nourished the soil and protected it from erosion for thousands of years. Removal of this protective cover led to many onsite and offsite effects. The onsite effect was the soil erosion and loss of soil productivity rendering sloping lands unproductive grasslands. Thwaites complained about the siltation of lowlands and river beds in the 1870 s at the height of the coffee industry. It is generally known that plantation land has lost on average not less than $20 \mathrm{~cm}$ of the top soil after the clearance of forests in the 19th century.

Thwaites managed to convince Sir Joseph Hooker, Director, Kew Gardens, regarding the seriousness of the situation in the colony. He cited examples of soil erosion in the uplands, and siltation of low-lying farmlands and river beds. These findings are corroborated by various Royal Commission reports produced in the late 19th and early 20th centuries. Hooker's concern prompted the Colonial Secretary to issue an administrative order banning the clearing of government forest land above the 1524m (5000 foot) contour. Even though this ban did not result in an immediate end to the clearing of forests in these areas, it has at least had a symbolic value in influencing the forestry policy of Colonial rulers of the island. Directors of the Royal Botanical Gardens, Peradeniya, who were concerned about the loss of endemic species from the highlands, in fact attempted ex-situ conservation in botanical gardens in order to preserve these species for future generations.

Another indirect effect had to do with changes to the land surface characteristics leading to alteration of water and energy fluxes. Forests are known to add more water to the atmosphere through transpiration than direct evaporation from the soil surface. This process can have an effect on the rainfall as well. It is also known that in the montane region condensation of mist on the canopy of the forests (also known as "occult rain") contributes water to the soil. The establishment of several protected areas in the montane region is a late but significant step in the right direction in conserving the forests and safeguarding the water resources of the island.

Most of the impacts reported are in the Mahaweli and Kelani Basins. Soil erosion in the Kelani Valley was serious enough to appoint several commissions to enquire into the causes of the siltation of the Kelani river bed obstructing navigation. The first such commission was the Kelani Valley Railway Commission (Sessional Paper No. XXII, 1895) which was to investigate the feasibility of constructing a railway in the Kelani valley as an alternative to river transport of estate produce. The commission report states that soil erosion was the reason for the extension of the railway line into the Kelani Valley because river transport, which had hitherto been one of the chief lines of communication between the Kelani Valley and Colombo, was fast becoming impassable owing to the formation of sand bars in the Kelani Ganga between the rapids above Yatiyantota and the union with the Sitawaka Ganga. The cause of silting up of the river bed was attributed to clearing of forests for plantations (A. Lewis, Assistant Commissioner of Forests). Another commission was appointed in 1904 to look into the problem of soil denudation in the Kelani valley. The Commission's conclusion was that erosion had been causing serious damage to crops and had been the principal cause of excessive floods. This twin problem was attributed to faulty land clearing and cultivation methods. It further added that regulation by law, not by nature, should be the means of avoiding such depredations in the future though there is little evidence that any of the recommendations of the commission were adopted.

In 1921, P.M. Lushington of the Indian Forest Service was appointed to inquire into the working of Ceylon forests. In his report he attributed accelerated soil erosion and silting up of stream beds to methods of cultivation which were adopted in large areas of the island. To save the catchments from further damage, he recommended that steps should be taken to prevent excessive denudation of the upland soil which was taking place in already alienated lands. He 
further recommended that further alienation of land in the catchment areas for forms of cultivation which leads to soil erosion to be stopped and that a suitable plant cover be maintained in estates and to discourage clean weeding. These recommendations were submitted in a report to the Estate Products Committee of the Board of Agriculture. As a result, a sub-committee was appointed to formulate suggestions with regard to the alienation of crown lands. The following recommendations made by the Committee were accepted by the Estate Products Committee.

1. No Crown lands with a slope of 60 degrees or over should be alienated except under the following conditions:

a. that such land if forest be retained in forest and not be opened for cultivation.

b. that such land if patana (grass) be used solely for afforestation.

2. At least $10 \%$ of all Crown land exclusive of stream reservations that were alienated after the passing of the necessary ordinance be kept in forest.

Forest planting was recommended on steep slopes and catchment areas, including stream reservations. Since this committee had not adequately treated the question of soil erosion, another committee was appointed in 1929 to look into the problem of soil erosion. All these developments were a result of grave environmental problems encountered by the country.

\section{CONCLUSIONS}

The sub-montane and montane forests, which were relatively free of large-scale human interference for thousands of years, were suddenly transformed into commercial agriculture in the $19^{\text {th }}$ century under the British colonial rule. This ecological transformation has proved to be irreversible and the forest cover with its multitude of species and animal habitats has been irreversibly lost. Its environmental implications are many and variable, with the removal of this protective cover having far reaching consequences to the country. The present paper focuses on the deforestation of the sub-montane and montane forests during the early phases of plantation agriculture in Sri Lanka and attempts to identify the extent of deforestation in relation to elevation zones, river catchments and administrative divisions during this period.

Pre-colonial Sri Lanka's highlands were little affected by human activity till the British took possession of the Kandyan Kingdom despite the fact that some human presence existed in the highlands during prehistoric and historic periods. Thus the colonial rule signifies a watershed in the ecological history of the island. Deforestation of the hill country of Sri Lanka can be largely attributed to coffee cultivation though chena cultivation under the new capitalist order has also played some role. Although most of the chena cultivation was at elevations below $1000 \mathrm{~m}$, some inroads were made into the higher elevations as well. Destruction of forests was not confined to areas that were suitable for agriculture but instead included steep slopes, which should have been kept under permanent tree cover.
Lack of knowledge about tropical conditions was clearly a problem in the agronomic practices of the British planters.

The rise and fall of the annual land sales mark the changing fortunes of the plantation industry. Two factors that affected the coffee industry in Sri Lanka are the price of coffee in the European markets and the coffee leaf disease. After the collapse of the coffee industry, most of the coffee areas were converted to tea plantations. Both commercial agriculture and development of transport infrastructure in the highlands attracted populations from other parts of Sri Lanka and also immigrant labour from South India. Since the soils of the abandoned plantation lands were too degraded for forests to reappear naturally, they therefore became grasslands.

Thus the coffee phase of plantation industry in the island is characterized by rapid scale deforestation, negative attitudes among the European planters and colonial officials towards forests, and ignorance regarding tropical agriculture among the European planters. Indiscriminate clearing of forests was therefore seen as an economic necessity and a way to combat diseases among Europeans in the colony - a situation that has had devastating longterm impacts on the forest cover, soil conditions and ecological balance in the upper elevations of the island.

Restoration of biodiversity in areas deforested for plantation crops should be attempted using the remaining forest patches in different areas of the highlands. The abandoned plantation lands should be rehabilitated with assisted regeneration of forests with locally available native species to minimize the damage caused by the plantation industry.

\section{ACKNOWLEDGEMENTS}

Prof. Michael Roberts kindly provided a copy of the Ferguson's Coffee Map for this study.

\section{REFERENCES}

Baranage, A (1983). Colonialism in Sri Lanka: The Political Economy of the Kandyan Highlands 18331886, Berlin:Mouton.

Bastianpillai, BESJ (1968). The Administration of Sir William Gregory, Governor of Ceylon 1872-77.

Bossuyt, Franky, Meegaskumbura, Madhava, Beenaerts, Natalie et al. (2004) Local Endemism within the Western Ghats-Sri Lanka Biodiversity Hotspot, Science, 306(15): 479-481.

Capper, J (1849). Descriptive Catalogue of the Woods of Ceylon, JRAS, 2(5): 135-55. Ceylon in the Jubilee Year Deraniyagala, (1992). ThePrehistory of Sri Lanka, Part 1, Colombo:Department of Archaeological Survey.

Duncan, James (2007). In the Shadows of the Tropics: Climate, Race and Biopower in Nineteenth Century Ceylon, Aldershot: Ashgate Publishing Limited.

Encyclopaedia of Ceylon (1902) Ceylon, www.1902encyclopedia.com/C/CEY/ceylon.html

Ferguson, J (1893) Ceylon in 1893, Colombo: Observer Press.

Ferguson, AM (1866-68) Ferguson's Ceylon Directory 
and Handbook and Supplement 1866 - 68, Roberts, Michael (1970). The Impact of Waste Lands Colombo Observer Press.

Juleff, Gill (1998). Ancient Iron and Steel Production at Samanalawewa, Sabaragamuwa University Journal, 1(1):3-9.

Laurie, Archibald Campbell (1896). A Gazetteer of the Central Province of Ceylon, Colombo: Government Press.

Perera, N.P. (1972). The Human Influence on the Vegetation of Sri Lanka Highlands, Vidyodaya Journal of arts, Science \& Humanities, 5(1 \&2): 13-28.

Premathilake, Rathnasiri (2006) Relationship of environmental changes in central Sri Lanka to possible prehistoric land-use and climate changes Palaeogeography, Palaeoclimatology, Palaeoecology 240 (3-4, 19) October:468-496.

Premathilaka, Ratnasiri (2012) Human used upper montane ecosystem in the Horton Plains, central Sri Lanka - a link to Late Glacial and early Holocene climate and environmental changes, Quaternary Science Reviews, 50(12 September): 23-42.

Premathilake, Rathnasiri and Risberg, Jan (2003). Late Quaternary climate history of the Horton Plains, central Sri Lanka. Quaternary Science Reviews, 22 (14): 15251541.

Premathilake R.T. \& Risberg J. (2003). Late Quaternary climate and vegetation history of the Horton Plains, Sri Lanka. Quaternary Science Reviews 22: 1525-1541.

Punyawardena B.V.R., Bandara T.M.J., Munasinghe M.A.K., Banda N.J. \& Pushpakumara S.M.V. (2003). Agro-ecological Regions of Sri Lanka. Natural Resources Management Center, Department of Agriculture, Peradeniya Legislation and the Growth of Plantations on the Technique of Paddy Cultivation British Ceylon: A Critique, Modern Ceylon Studies, 1(2): 157-198.

Sessional Paper No. XXII (1895) Reports of the Kelani Valley Railway Commission, Colombo: Ceylon Government Press.

Tennent, Emerson, (1860). Ceylon; an Account of the Island Physical, Historical, Vol. I, LondonVincent F D'A (1882). Report on the Conservation and Administration of Crown Forests in Ceylon, Sessional Paper No. 43 Colombo: Ceylon Government Press.

Vanden Driesen, I (1953). Coffee Cultivation in Ceylon (1), Ceylon Historical Journal, 3(1): 31-61.

Wallace, A. R. (1876) The Geographical Distribution of Animals, London: Macmillan.

Webb, James LA (2002). Tropical Pioneers: Human Agency and Ecological Change in the Highlands of Sri Lanka, 1800-1900, Athens: Ohio University Press.

Wickramagamage, P(1990). Man's Role in the Degradation of Soil and Water Resources in Sri Lanka: A Historical Perspective, Journal of the National Science Council of Sri Lanka, 18(1): 1-16.

Wickramagamage, P. (1995). Pedo-geomorphological evidence of climatic change in the Horton Plains, In University of Tsukuba (Ed.) Report of Research Project on Global Environmental Change, 3:390-414

Wimaladharma, K. P. (1977) Land use Adjustment in the Mid-Country of Sri Lanka: An Examination of the Nilambe-Atabage Catchment Development Project, Unpublished MA Dissertation, University of Colombo: Colombo. 